\title{
Comparative studies on the quality of sandesh from cow milk chhana with soy-milk chhana addition
}

\author{
Shireen Akther ${ }^{1}$, Sha Md. Shahan Shahriar ${ }^{2}$, \\ Md. Kauser-UL Alam ${ }^{1}$, Abdul Matin ${ }^{1}$, Nazmul Sarwar ${ }^{1}$
}

1 - Department of Food Processing and Engineering, Chittagong Veterinary and Animal Sciences University, Chittagong, Bangladesh

2 - Department of Applied Chemistry and Chemical Engineering, Rajshahi University, Rajshahi, Bangladesh

\begin{tabular}{l} 
Keywords: \\
Milk \\
Sandesh \\
Cow \\
Soy \\
Chhana \\
Quality \\
\hline \\
Article history: \\
Received 17.04.2017 \\
Received in revised \\
form 18.06.2017 \\
Accepted 05.09 .2017 \\
\hline Corresponding \\
author: \\
Shireen Akther \\
E-mail: \\
shireen_cvasu@ \\
yahoo.com \\
\hline
\end{tabular}

DOI: $10.24263 / 2304-$ 974X-2017-6-3-11

\section{Abstract}

Introduction. Sandesh is a popular chhana based sweetmeat of Bangladesh. The present study was carried out to compare the quality of Sandesh made from Cow-milk Chhana and along with addition of different level of Soymilk Chhana.

Materials and methods. Four different types of Sandesh, namely $\mathrm{S}_{1}$ (from $100 \%$ cow milk chhana), $\mathrm{S}_{2}$ (75\% cow milk chhana $+25 \%$ soy milk chhana), $\mathrm{S}_{3}(25 \%$ cow milk chhana + $75 \%$ soy-milk chhana) and $\mathrm{S}_{4}(100 \%$ soy-milk chhana) were processed in the Laboratory of the Department of Food Processing and Engineering, Chittagong Veterinary and Animal Sciences University. Prepared sandesh samples were analyzed for moisture, protein, fat, ash, carbohydrate content, $\%$ acidity and sensory properties. The acceptability of Sandesh samples were studied by a taste panel consisting of 15 panelists.

Results and discussions. Results indicated that the moisture content were $22.53 \pm 0.12,22.95 \pm 0.20,23.54 \pm 0.22$ and $25.44 \pm 0.17 \%$ respectively; protein content $21.87 \pm 0.32$, $23.02 \pm 0.17,25.92 \pm 0.42$ and $29.62 \pm 0.23 \%$; fat content $20.44 \pm 0.05,19.02 \pm 0.03,17.00 \pm 0.05$ and $16.42 \pm 0.10 \%$; ash content $0.88 \pm 0.04,1.39 \pm 0.03,1.53 \pm 0.04$ and $1.95 \pm 0.02 \%$; acidity $0.05,0.033,0.023$ and $0.22 \%$ and carbohydrate content $\quad 34.28 \pm 0.22, \quad 33.62 \pm 0.16, \quad 32.01 \pm 0.59$ and $27.15 \pm 0.31 \%$ respectively. On the basis of sensory evaluation of colour, flavor, texture and overall acceptability, Sandesh made from fresh cow milk chhana ensure highest acceptability and liked very much. Sandesh made with $75 \%$ Cow-milk Chhana and 25\% Soy-milk Chhana $\left(\mathrm{S}_{2}\right)$ was also liked moderately and other types $\left(\mathrm{S}_{3}\right.$ and $\mathrm{S}_{4}$ ) were not acceptable.

Conclusions. Soy-milk Chhana can be used as a replacement of Cow-milk Chhana in preparation of Sandesh. 


\section{Introduction}

Soybean (Glycine max) is a new prospective oil crop in Bangladesh. It is regarded as an ideal food for the people of Bangladesh as it contain high quantity of protein and superior quantity of edible oil. Most of the people of our country can't afford to get proteinenriched food like fish, meet, egg, milk etc. due to their high cost. So, to supplement protein at low cost, soybean should be cultivated in more areas in our country. Soybean cultivation is highly concentrated geographically, with only four countries - USA, Brazil, Argentina and China - accounting for almost $90 \%$ of world output [1].

Soybean accounts for approximately $50 \%$ of the total production of oil seed crop in the world [1]. Soybean are not consumed directly, but are processed into a large number of variety of popular products. The most of popular soybean products are Temphe (fermented soybeans), Tahu or Tofu (soybean curd), Taoge (soybean sprouts), Kecap (soy-sauce), Tauco (fermented mixture) which are usually consumed as side dished with rice. Other popular soybean products are yaba, soy-milk and sere.

Soybeans are an excellent and cheap source of calories and quality protein. They content $35-40 \%$ protein and $18-20 \%$ fats [2] and can there for be useful combating protein calories malnutrition in the poorer starter of population. Regarding this soy-milk (prepared from soybean) can be used as replaced to milk to meet deficiency of whole milk.

Milk is one of the most important commodities entering trade and required in everyday life as an article of food. The basic public health and economic considerations require that consumers should be provided with pure milk, free from pathogenic bacteria. To maintain quality standards, control operations have to be performed at all stages of the production of milk which include maintenance of sanitary conditions of byres; cleanliness of utensils and of the milking machines, if used; and care during storage and handling. Any kind of adulteration at the producing of supplying centre, by carries or by middlemen, has to be prevented. The need for having uniform methods for assessing the quality of milk at the time of purchase or sale is, therefore, obvious. Milk is widely used in the preparation of sweetmeats. The sweetmeats made from milk are delicious, wholesome nutritious and very popular items in Bangladesh. Form births to death in each sphere of life milk sweetmeats have occupied a significant place in our society. On occasions like birthdays marriages, funeral ceremonies, religious festivals and guest entertainment, everywhere sweetmeats are inevitable.

The importance of sweetmeat in this subcontinent has been recognized since five thousand years ago [3]. It is reported that about $10 \%$ of the total milk production in Bangladesh are used for the preparation of chhana and finally for sweetmeat milk. In India $40 \%$ of total milk is used for chhana which is mainly used for sandesh preparation [4]. In Bangladesh there are some areas where sweetmeat and very much famous e.g.'monda' of Muktagacha (Mymensingh), 'Chomachom' of porabari (Tangail), 'Resomalai' of comilla, Kachhagolla of Natore, 'Dahi' of Bogra etc. But there is no such specific area, which is famous for sandesh. Sandesh, the highest priced sweetmeat is widely manufactured throughout the country and in every area there are some sweetmeat shops which are particularly famous for this grand item.

Sandesh, a chhana based sweetmeat is very popular in Bangladesh because of its high palatability. It is also popular in West Bengal and some parts of Assam, Tripura, Orissa, Myanmar, Bihar, and some parts of India. The demand for sandesh is steadily growing [5].

Sandesh is usually prepared from cow's milk because it produces soft body with fine and uniform grains size product which are considered defects in soft grade sandesh. Although cow milk is considered highly suitable for chhana making [6], but a few reports 
indicates that modification of buffalo milk for chhana production yields acceptable quality sandesh $[7,8]$.

Sandesh is a kind sweetmeat, which is prepared by heating the mixture of freshly, prepare chhana and ground sugar on a slow fire. Varieties of sandesh are available in the market which may be grossly classified into three main groups such as-first soft grade, second hard grade and third high moisture grade depending upon their physical qualities and chemical composition. In India, about 4 percent of the total milk is used for chhana preparation [4]. Mostly cow milk is used to obtain good quality chhana and its subsequent based sweetmeats. This has limited the availability of cow for fluid consumption.

Sweetmeat, specially, sandesh is one of the most important pleasant and charming foods to most of the people of the country. Sweetmeats are extensively used, chiefly along with other foods due to their good flavour and high food value. They are also easily digested. However, sandesh is a chhana based sweetmeat, it is very vital to health because of its fairly high protein and fat content, minerals, specially, calcium and phosphorus and also fat soluble vitamins particularly, vitamin A and D content. Not only in our country but also in this subcontinent, the importance of sweetmeat has been recognized since five thousand years ago [3]. Limited works in connection with quality of laboratory made sandesh from cow's milk was done in different areas of Mymensingh, Jessore, Khulna and Satkhira districts and also different districts of Bangladesh. Under the above circumstances the present investigation was planned with preparation of Sandesh from fresh cow's milk Chhana and along with addition of different level of Soy-milk Chhana, compare the quality of prepared Sandesh on the basis of proximate and organoleptic properties.

\section{Materials and methods}

The experiment was conducted in the laboratory of the Department of Food Processing and Engineering, Chittagong Veterinary and Animal Sciences University, Chittagong.

\section{Preparation of sandesh}

For making chhana, cow milk samples were collected from dairy farm located in Chittagong city, Bangladesh.

\section{Preparation of soy-milk}

Fresh soybean seeds were collected from local markets. The method used by Kapoor, et al (1977) was modified slightly for making soy-milk [9].

Socking of soybean seeds. For preparation of soy-milk, $2000 \mathrm{gm}$ of fresh and clean soybean seeds were soaked overnight in 0.5 percent sodium bicarbonate to make the husk soft and also to remove bitterness.

Removal of husk. After socking overnight outer coating of the seeds (husk) were removed physically by means of pressure applied by two hands. After removing all husks, the collected seeds were washed in fresh and clean cold water.

Preparation of soy-milk. One litre $(1000 \mathrm{ml})$ of clean water was added with the washed soybean seeds and about 2-3 gm of cardamom was also added to remove the beany flavour present in soybean seeds. The mixture was grinded in a grinder for about thirty to forty minutes. After satisfactory grinding the residue of soy-milk was removed by 
filtering with a fine muslin cloth and the soy-milk was collected in a beaker. At the first time about 2 liter of soy-milk was obtained.

\section{Chhana making}

Chhana was prepared by boiling both cow milk and soy-milk separately into stainless steel pan for about ten minutes and was cooled down slightly and as coagulant whey was added at a temperature of $70^{\circ} \mathrm{C}$. Lumps of casein were formed as soon as the whey was added to the boiled milk, which is generally known as chhana. The content was then allowed to stay for few minutes for complete coagulation of chhana. About 5 to 10 minutes after coagulation, contents were gradually poured into a coarse muslin cloth with four corners raised to allow free drainage of whey. When the transfer of whey was completed the four corners of the cloth were tied together drainage of whey. The coagulum was then carefully removed and weighed.

Four different types of sandesh were prepared by different combination of cow milk and soy-milk their combinations are shown below.

\section{Ingredients of Sandesh}

Table 1

\begin{tabular}{|c|c|c|c|}
\hline *Sample Type & $\begin{array}{c}\text { Cow milk chhana } \\
(\mathrm{gm})\end{array}$ & $\begin{array}{c}\text { Soy-milk chhana } \\
(\mathrm{gm})\end{array}$ & Sugar (gm) \\
\hline $\mathrm{S}_{1}$ & 500 & - & 175 \\
\hline $\mathrm{S}_{2}$ & 375 & 125 & 175 \\
\hline $\mathrm{S}_{3}$ & 125 & 375 & 175 \\
\hline $\mathrm{S}_{4}$ & - & 500 & 175 \\
\hline
\end{tabular}

*Sample Type $\mathrm{S}_{1}$ (Only cow milk chhana)

*Sample Type $\mathrm{S}_{2}$ (Cow milk chhana: Soya milk chhana=3:1)

*Sample Type $\mathrm{S}_{3}$ (Cow milk chhana: Soy milk chhana $=1: 3$ )

*Sample Type $\mathrm{S}_{4}$ (Only cow milk chhana)

Freshly made chhana was broken into bits. Sugar $(35 \%$ by wt of total chhana was mixed into it and was kneaded. Then chhana was taken into an iron pan. The mixture is baked by slow heating with continuous stirring and then scraping with the help of a specially made flat type light wooden ladle, until pat formation stage appeared. After sufficient cooling at room temperature, it was then worked into desired size and shape. No flavour of colour was added so that making of the original clolour and flavour could be avoided. Sandesh were kept in clean polythene bag and preserved in the refrigerator at 4 ${ }^{\circ} \mathrm{C}$. 


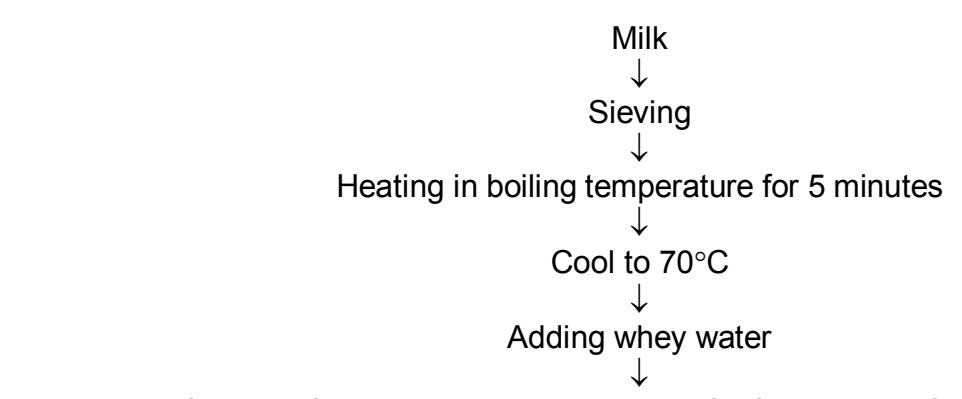

The lumps of case in formed were allowed to stay for few minutes for complete coagulation

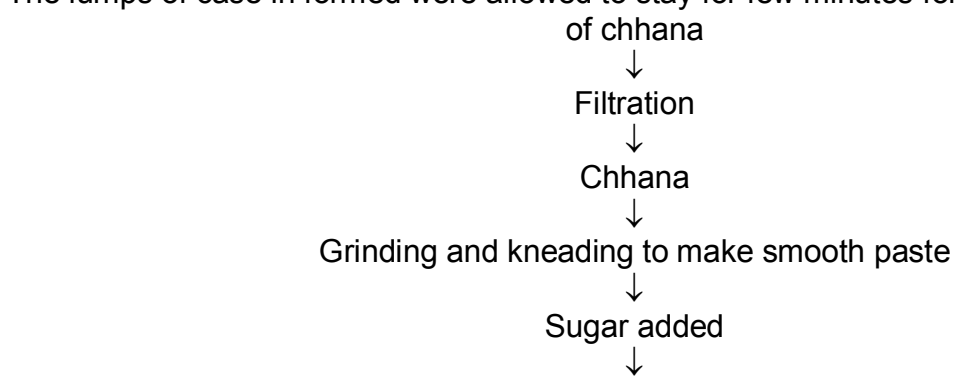

Slow heating with continuous stirring baked the mixture until pat formation stage appeared

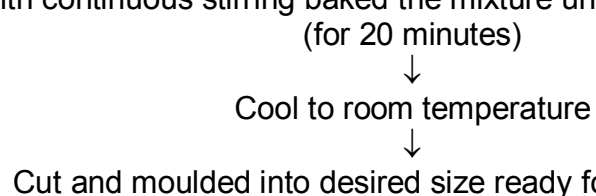

Figure 1. Schematic diagram for sandesh preparation

\section{Chemical Analysis}

Proximate composition (Moisture, Protein, Fat, Ash and Carbohydrate). Moisture, Protein, Fat and Ash of prepared sandesh samples were analyses in triplicate following standard procedures [10]: Moisture content by drying in an oven at $105^{\circ} \mathrm{C}$ for $24 \mathrm{~h}$; Crude protein content $(\mathrm{Nx6.25)}$ by the Kjeldahl method using an Auto Kjeldahl System, Lipid by ether extraction and Ash by incineration in a muffle furnace at $600^{\circ} \mathrm{C}$ for $6 \mathrm{~h}$. Carbohydrate content were calculated by difference method i.e., $\%$ Carbohydrate $=100-(\%$ Moisture $+\%$ Protein $+\%$ Fat $+\%$ Ash $)$

Acidity. 5 g sample was taken and blended, homogenized in a blender with distilled water and carefully transfer to a $250 \mathrm{ml}$ beaker. The mixture was boiled for $1 \mathrm{hr}$ periodically adding water to replace the loss by evaporation. Cooled and transferred to a $100 \mathrm{ml}$ volumetric flask. Then volume was made to $100 \mathrm{ml}$ and filtered. $30 \mathrm{ml}$ filtered liquid was titrated against $0.1 \mathrm{~N} \mathrm{NaOH}$ using phenolphthalein as an indicator. The titration was done in triplicate and titratable acidity was calculated from the following relationship Ranganna (1994) [11]. 


$$
\begin{gathered}
\qquad \text { Food Technology }- \\
\% \text { Acidity }=\frac{\text { Eq.wt of lactic acid } \times \text { Normality of NaOH } \times \text { Volume } \times \text { T.V }}{1000 \times \text { wt of sample } \times \text { ml of extract taken for estimation }} \times 100 .
\end{gathered}
$$

Sensory evaluation. The consumer acceptability of developed products was evaluated by a testing panel. The panelists were untrained and selected from the students, teachers and employees of the Department of Food Processing and Engineering, Chittagong Veterinary and Animal Sciences University, Chittagong. The panelists (15) were asked to assign appropriate score to each product tested on a 1 to 9 point hedonic scale for characteristic colour, flavour, sweetness and overall acceptability of various mixed samples. The scale was arranged such that; $9=$ Like extremely, $8=$ Like very uch, $7=$ Like moderately, 6 = Like highly, $5=$ Neither like nor dislike, $4=$ Dislike slightly, $3=$ Dislike moderately, 2 = Dislike very much, and $1=$ Dislike extremely. The results were evaluated by Analysis of Variance and Duncan's New Multiple Range Test procedure of the statistically analysis system [12].

\section{Results and discussions}

Four different types of sandesh were prepared in the laboratory with different combinations of cow milk chhana and soy-milk chhana. The prepared sandesh sample types were designated as $\mathrm{S}_{1}\left(100 \%\right.$ cow milk chhana), $\mathrm{S}_{2}(75 \%$ cow milk chhana $+25 \%$ soy-milk chhana), S3 (25\% cow milk chhana $+75 \%$ soy-milk chhana), $\mathrm{S}_{4}(100 \%$ cow milk chhana).

\section{Chemical composition analysis of sandesh}

Moisture content. The moisture content were $22.53 \pm 0.12,22.95 \pm 0.20,23.54 \pm 0.22$ and $25.44 \pm 0.17 \%$ in $\mathrm{S}_{1}, \mathrm{~S}_{2}, \mathrm{~S}_{3}$, and $\mathrm{S}_{4}$ type sandesh respectively (Table 2). It is observed that $\mathrm{S} 1$, type sandesh had the lowest moisture content and it was gradually increased in in $\mathrm{S}_{1}, \mathrm{~S}_{2}, \mathrm{~S}_{3}, \mathrm{~S}_{4}$, type sandesh. The differences in moisture might be due to differences in level of fat in these four-type sandesh on one hand and due to the presence of varied proportions of soy-milk chhana solids in chhana on the other hand. This could be attributed due to greater binding capacity of soy solids specially protein $[13,14,15]$. De and Ray (1954) also reported that capacity of chhana to retain moisture is essentially is the function of milk protein which did increase with greater levels of soy-milk in milk [6]. Sarker (1975) reported that acceptable quality of sandesh contain $234.00 \mathrm{gm} / \mathrm{kg}$ moisture [16]. The moisture content of the prepared sandesh was in same range as described by Poonia (2015) [24].

Protein. The protein percentage of $\mathrm{S}_{1}, \mathrm{~S}_{2}, \mathrm{~S}_{3}$ and $\mathrm{S}_{4}$ types of sandesh were $21.87 \pm 0.32$, $23.02 \pm 0.17,25.92 \pm 0.42$ and $29.62 \pm 0.23 \%$ respectively. It was observed that increase of soy-milk chhana enhanced the protein percentage of sandesh. This might be due to the higher percentage of protein in soy-milk chhana than in cow milk chhana which cause increase in protein percentage in sandesh. Jailkhani and Sukumar (1980) observed 170.03 $\mathrm{gm} / \mathrm{kg}$ protein in a better quality sandesh [17] and protein content of prepared sandesh were identical to Poonia (2015) [24]. 
Fat content. The fat in $S_{1}, S_{2}, S_{3}$ and $S_{4}$ types of sandesh were 20.44 \pm 0.05 , $19.02 \pm 0.03,17.00 \pm 0.05$ and $16.42 \pm 0.10 \%$ respectively. It was obserbed that $S_{1}$ type sandesh had highest percentage of fat and $\mathrm{S}_{4}$ type of sandesh had the lowest percentage of fat. Enhancing the proportion of soy-milk chhana in the mixture affected the fat content of sandesh adversely. Generally soy-milk chhana contains low level of fat.

Ash content. The ash content of in $\mathrm{S}_{1}, \mathrm{~S}_{2}, \mathrm{~S}_{3}$ and $\mathrm{S}_{4}$, types of sandesh were $0.88 \pm 0.04$, $1.39 \pm 0.03,1.53 \pm 0.04$ and $1.95 \pm 0.02 \%$ respectively. It was shown that the different types of sandesh have the similar ash content and those were in same range described by Poonia (2015) [24]. Katra and Bhargava, (1994) reported that soy-milk contains 0.73 percent ash which is similar to average ash content of milk [18]. Jailkhani and sukumar (1980) reported better quality sandesh contain $16.6 \mathrm{~g} / \mathrm{kg}$ ash [19].

Carbohydrate content. The carbohydrate content of $\mathrm{S}_{1}, \mathrm{~S}_{2}, \mathrm{~S}_{3}$ and $\mathrm{S}_{4}$ types of sandesh were $34.28 \pm 0.22,33.62 \pm 0.16,32.01 \pm 0.59$ and $27.15 \pm 0.31 \%$ respectively. There was no significant difference among the carbohydrate content of different sandesh sample. The carbohydrate content of milk is usually $4.9 \mathrm{gm} / 100 \mathrm{gm}$ and for soy-milk, it is $3.2 \mathrm{gm} / 100 \mathrm{gm}$ [20]. So it was usual that sandesh containing higher percentage of soy chhana would have lower percentage of total carbohydrate content because of lower carbohydrate content in soy-milk. Acceptable quality sandesh contain $16.6 \mathrm{gm} / \mathrm{kg}$ of carbohydrate [21].

Acidity. The percentage of acidity of $\mathrm{S}_{1}, \mathrm{~S}_{2}, \mathrm{~S}_{3}$ and $\mathrm{S}_{4}$ types of sandesh were 0.05 , $0.033,0.023$ and 0.022 respectively. In respect of the acidity content types $S_{1}$ had lowest percentage of acidity and $\mathrm{S}_{4}$ the highest. Our result agreed with the result of Jeoun et al (1995) [22]. So, increased acidity of $\mathrm{S}_{1}, \mathrm{~S}_{2}, \mathrm{~S}_{3}$ and $\mathrm{S}_{4}$ samples were due to addition of soymilk chhana with them.

Chemical compositions of sandesh product

Table 2

\begin{tabular}{|c|c|c|c|c|c|c|}
\hline $\begin{array}{c}\text { Sample } \\
\text { Type }\end{array}$ & $\begin{array}{c}\text { Moisture } \\
\text { content }(\mathbf{\%})\end{array}$ & $\begin{array}{c}\text { Ash } \\
(\mathbf{\%})\end{array}$ & $\begin{array}{c}\text { Protein } \\
(\mathbf{\%})\end{array}$ & $\begin{array}{c}\text { Fat } \\
(\%)\end{array}$ & $\begin{array}{c}\text { Acidity } \\
\mathbf{( \% )}\end{array}$ & $\begin{array}{c}\text { Carbohy- } \\
\text { drate }(\%)\end{array}$ \\
\hline $\mathrm{S}_{1}$ & $22.53 \pm 0.12$ & $0.88 \pm 0.04$ & $21.8 \pm 0.32$ & $20.44 \pm 0.05$ & 0.05 & $34.28 \pm 0.22$ \\
\hline $\mathrm{S}_{2}$ & $22.95 \pm 0.20$ & $1.39 \pm 0.03$ & $23.0 \pm 0.17$ & $19.02 \pm 0.03$ & 0.033 & $33.62 \pm 0.16$ \\
\hline $\mathrm{S}_{3}$ & $23.54 \pm 0.22$ & $1.53 \pm 0.04$ & $25.9 \pm 0.42$ & $17.00 \pm 0.05$ & 0.023 & $32.01 \pm 0.59$ \\
\hline $\mathrm{S}_{4}$ & $25.44 \pm 0.17$ & $1.95 \pm 0.02$ & $29.0 \pm 0.23$ & $16.42 \pm 0.10$ & 0.022 & $27.15 \pm 0.31$ \\
\hline
\end{tabular}

* Sample $\mathrm{S}_{1}$ (only cow milk chhana)

*Sample $\mathrm{S}_{2}$ (only cow milk chhana: Soy-milk chhana =3:1)

*Sample $\mathrm{S}_{3}$ (cow milk chhana: Soy-milk chhana $=1: 3$ )

*Sample $\mathrm{S}_{4}$ (only soy- milk chhana)

\section{Sensory evaluation of the products}

The mean score for colour, flavour, texture and overall acceptability of the sample are evaluated and the mean score of their responses are presented in Table 3. A two-way analysis of variance (ANOVA) was carried out and results revealed that there was 
significant $(\mathrm{P}<0.01)$ differences in colour acceptability among the prepared sandesh samples, since the calculated F-value was greater than tabulated F-value so the colour of control (Sample $S_{1}$ ) sandesh was most preferred and also sample $S_{1}$ and sample $S_{2}$ had on significant difference for colour. Sample $\mathrm{S}_{3}$ and $\mathrm{S}_{4}$ are not equally acceptable. The colour of the samples $S_{1}$ and $S_{2}$ were significantly better than samples $S_{3}$ and $S_{4}$. Highly preference of colour sample- $\mathrm{S}_{1}$ among the sample $\mathrm{S}_{2}, \mathrm{~S}_{3}$ and $\mathrm{S}_{4}$.

In case of flavour preference among the prepared sandesh sample, two-way ANOVA shown that significantly $(\mathrm{P}<0.01)$ affected flavour acceptability since the calculated Fvalue was greater than the tabulated F-value. The results (Table 3) showed that the flavour of the control (Sample $\mathrm{S}_{1}$ ) was most preferred and significantly different than the other samples. The flavor of the sample $S_{1}$ was highly preferred among the sample $S_{2}, S_{3}$ and $S_{4}$. In case of texture preference among the samples, a two-way ANOVA showed that significantly $(\mathrm{P}<0.01)$ affected texture acceptability since the calculated $\mathrm{F}$-Value was greater than the tabulated $\mathrm{F}-$-value. The results (Table 3) showed that the texture of the control (Sample $\mathrm{S}_{1}$ ) was most preferred and significantly different than other sample. As shown in Table 3 the sample $S_{2}$ and S3 had on significant deference. Highly preference of texture of sample $S_{1}$ than the sample $S_{2}, S_{3}$ and $S_{4}$. In case of texture preference among the sample, a two-way ANOVA showed that significantly $(\mathrm{P}<0.01)$ affected texture acceptability since the calculated F-Value was greater than the tabulated F-value. The results (table-3) showed that the texture of the control (Sample $\mathrm{S}_{1}$ ) was most preferred and significantly different than other sample. As shown in Table 3 the samples $S_{2}$ and $S_{3}$ had no significant difference. $S_{1}$ was highly preferred than other sample types $S_{2}, S_{3}$ and $S_{4}$ in terms of texture quality. Interrelationship was found among textural parameters and composition in all samples of sandesh as described by Khamrui and Solanki (2010) [23].

It is apparent from the results of ANOVA that there was significant $(\mathrm{P}<0.01)$ difference in overall acceptability among 1 the prepared sandesh samples, since the calculated $\mathrm{F}-$ value was greater than the tabulated F-value. The result (Table 3) showed that the overall acceptability of the control (Sample $\mathrm{S}_{1}$ ) was most preferred. Sample $\mathrm{S}_{3}$ and Sample $\mathrm{S}_{4}$ had no significant difference. Lastly highly preference overall acceptability Sample $S_{1}$ among the samples-

Table 3

Mean sensory scores of Sandesh samples

\begin{tabular}{|c|c|c|c|c|}
\hline \multirow{2}{*}{$\begin{array}{l}\text { Sandesh } \\
\text { Types }\end{array}$} & \multicolumn{4}{|c|}{ Sensory attributes } \\
\hline & Colour & Flavour & Texture & $\begin{array}{c}\text { Overall } \\
\text { Acceptability }\end{array}$ \\
\hline Sample $\mathrm{S}_{1}$ & $8.533^{\mathrm{a}}$ & $8.067^{\mathrm{a}}$ & $6.933 \mathrm{a}^{\mathrm{a}}$ & $7.200^{\mathrm{a}}$ \\
\hline Sample $S_{2}$ & $7.867^{\mathrm{a}}$ & $6.800^{b}$ & $5.867^{\mathrm{b}}$ & $5.800^{b}$ \\
\hline Sample $\mathrm{S}_{3}$ & $7.000^{b}$ & $6.000^{\mathrm{c}}$ & $5.333^{b}$ & $5.600^{b c}$ \\
\hline Sample $\mathrm{S}_{4}$ & $6.200^{c}$ & $5.133^{d}$ & $4.267^{\mathrm{c}}$ & $4.933^{\mathrm{c}}$ \\
\hline L.S.D & 0.6875 & 0.6896 & 0.8997 & 0.7955 \\
\hline
\end{tabular}

Means with same superscripts with in a column are not significantly different at $\mathrm{P}<0.01$. 


\section{Conclusions}

Different types of sandesh named $\mathrm{S}_{1}$ (from $100 \%$ cow milk chhana), $\mathrm{S}_{2}$ (75\% cow milk chhana $+25 \%$ soy milk chhana), $\mathrm{S}_{3}\left(25 \%\right.$ cow milk chhana $+75 \%$ soy-milk chhana) and $\mathrm{S}_{4}$ $(100 \%$ soy-milk chhana) were prepared to compare the quality. Results indicated that moisture content in four types of sandesh were approximately $22.53 \pm 0.12,22.95 \pm 0.20$, $23.54 \pm 0.22$ and $25.44 \pm 0.17 \%$ respectively; protein content $21.87 \pm 0.32,23.02 \pm 0.17$, $25.92 \pm 0.42$ and $29.62 \pm 0.23 \%$; fat content $20.44 \pm 0.05,19.02 \pm 0.03,17.00 \pm 0.05$ and $16.42 \pm 0.10 \%$; ash content $0.88 \pm 0.04,1.39 \pm 0.03,1.53 \pm 0.04$ and $1.95 \pm 0.02 \%$; acidity 0.05 , $0.033,0.023$ and $0.022 \%$ and carbohydrate content $34.28 \pm 0.22,33.62 \pm 0.16,32.01 \pm 0.59$ and $27.15 \pm 0.31 \%$. Statistical analysis on the response of taste panel on the sensory properties of sandesh revealed that the colour, flavour, texture and overall acceptability of different sandesh were significantly affected. The overall acceptability of sample type $\mathrm{S}_{1}$ was found to be more acceptable than those of sample $\mathrm{S}_{2}, \mathrm{~S}_{3}$ and $\mathrm{S}_{4}$. Sandesh with $75 \%$ cow milk chhana and $25 \%$ Soy-milk Chhana $\left(\mathrm{S}_{2}\right)$ was also liked moderately and other types $\left(\mathrm{S}_{3}\right.$ and $\mathrm{S}_{4}$ ) were not acceptable in terms of organoleptic properties but have good nutritive quality. Addition of flavor substitute will enhance the organoleptic properties of Soy-milk Chhana and it can be used as a replacement of Cow-milk Chhana in preparation of Sandesh.

\section{References}

1. Thoenes P. (2007), Background paper for the Competitive Commercial Agriculture in Sub-Saharan Africa (CCAA) Study, Food and Agriculture Organization of the United Nations.

2. Schroder D.J., Euiot J.I., Juckson H. (1986), Nutritional studies on Soyabean curd produced by calsium sulphate precipitation of Soyabean Milk, Journal of Food Science, 38, pp. 1091.

3. Tiwari B.D., Sukumar D.C. (1976), Standardardization of the industrial Methods of Production of Dried chhana, Indian Journal of Dairy Science, 29, pp. 212.

4. Mathur B.N. (1991), Infigeneous milk products of India. The relared research and tecnological requirements, Indian Dairyman, 43(61).

5. Sen D.C., Rajorhia G.S. (1985), Current status of Sandesh production in India, Indian Dairyman, 37, pp. 453.

6. De S., Ray S.C. (1954), Studies on the indigenous method of chhana making influence of condition of coagulation and type of milk on the production of chhana, Indian Journal of Dairy Science, 7(3), pp.133-125.

7. Jagtiani J.K., Lyergar, kapur N.S. (1960), Studies on utilization of buffalo milk for chhana making, Journal of Food Science, 9, 46.

8. Kaundu S.S., De S. (1972), Studies on production of sandesh from buffalo milk, Indian Journal of Dairy Science, 159.

9. Kapoor U., Dutta I.C., Quardi M.A., Kushwah H.S. (1977), Note on chemical analysis and acceptability of soy-milk, Indian journal of agricultural sciences, 47, pp. 172176.

10. AOAC (2016), Official Methods of Analysis of the Association of Official Analytical Chemist, $20^{\text {th }}$ Edition, Washington, DC.

11. Ranganna S. (1994). Hand book of analysis of quality control for fruits and vegetable products, 2nd Edition. TATA McGraw Hill publication, Co. Ltd. New Delhi, pp. 46. 
12. SAS (1985), SAS Users guide: Statistics, Version 5th ed. SAS institude. Inc. Cary, $\mathrm{NC}$.

13. Circle S.J., Johnson D.W. (1958), Edible isolated soyabean protein, Processed plant protein food stuff, Althul, A. M. (Ed), Academic press Inc. New York.

14. Sharma A.K. (1978), Soyabean protein conecntrates and isolates, Pharmbit, 1, pp. 2937.

15. Rajor R.B., Gupta S.K. (1982), Technological studies on the utilization of buttermilk and Soyabean for manufacture of soft ice-cream. PhD thesis, $\mathrm{Pb}$. Unive. Chandigrah.

16. Sankar J.K. (1975), Studies on the composition of Sandesh, J. Sci. Tech. India, 12(6), pp. 321.

17. Sukumar D.E., Sukumar E. (1976), Chhana and Chhana based Sweets, IndianDairyman, 28(3), pp. 105-109.

18. Katra R.V., Bhargava V.N. (1994), Studies of the manufacture of Rasogolla from buffaloes and soymilk blends, Indian Journal of Dairy Science, 47(11), pp. 981-986.

19. Jaikhani V.K., De S.U. (1980), Utilization of goat milk for chhana making, Indian Journal of Dairy Science, 33(1), pp. 29-33

20. Swaminathan M., Bhagavan R. K. (1959), Our Food. Ganensh \& Co Madras, India, p. 17.

21. Mandal A.K., Bandyopadhyay A.K., Ghatak P. K. (1996), Chemical and sensory quality of Chhana and Sandesh from soy-milk and blends with cow and buffalo milk, Indian Journal of Dairy and Biosciences, 7, pp. 25-29.

22. Jeoun K.S., Kim Y.J., Park S.I. (1995), Preparation and characteristics of yogurt from milk added with soy milk and brown rice, Korean Journal of Food Science and Technology, 27(1), pp. 47-55.

23. Khamrui K., Solanki D.C. (2010), The relationship of textural characteristics with composition of sandesh produced from various market milk classes, International journal of dairy technology, 63(3), pp. 451-456.

24. Poonia A. (2015), Developments in the manufacture and preservation of sandesh: A review, Asian Journal of Dairy and Food Research, 34(3), pp.173-179. 